Western University Scholarship@Western

Centre for the Economic Analysis of Property Centre for the Economic Analysis of Property

Rights. Economics and Law Workshop Papers

Rights

1983

\title{
Communal Property Rights: The Papua New Guinean Experience
}

Michael Trebilcock

Follow this and additional works at: https://ir.lib.uwo.ca/economicsceapr_el_wp

Part of the Economics Commons

Citation of this paper:

Trebilcock, Michael. "Communal Property Rights: The Papua New Guinean Experience." Centre for the Economic Analysis of Property Rights. Economics and Law Workshop Papers, 83-07. London, ON: Department of Economics, University of Western Ontario (1983). 
ECONOMICS AND LAW WORKSHOP

83-07

COMMUNAL PROPERTY RIGHTS: THE

PAPUA NEW GUINEAN EXPERIENCE

BY: Michael J. Trebilcock

Faculty of Law

University of Toronto

4032 SSC Thursday April 7, 1983 4:00 p.m.

* This paper draws on and develops work undertaken by the author and Jack L. Knetsch, Land Policy and Economic Development in Papua New Guinea (Institute of National Affairs, Port Moresby, P.N.G., 1981) during a short visit to Papua New Guinea in 1980 and further work undertaken by the author as a member of a Prime Ministerial Task Force on Customary Land Issues during a sabbatical leave in Papua New Guinea in 1982.

Department of Eccnomics Library
\[ A \square 01983 \]
University of Western Ontario

Major funding for the Centre for Economic Analysis of Property Rights has been provided by the Academic Development Fund, The University of Western Ontario. Additional support has come from The Bureau of Policy Coordination, Consumer and Corporate Affairs. The views expressed by individuals associated with the Centre do not reflect official views of the Centre, The Bureau of Policy Coordination, or The University of Western Ontario.

Subscriptions to the Workshop papers and the Working Paper Series are $\$ 40$ per year for institutions and $\$ 25$ per year for individuals. Individual copies, if available, may be purchased for $\$ 3$ each. Address all correspondence to John Palmer, Centre for Economic Analys is of Property Rights, The University of Western Ontario, London, Ontario, CANADA N6A 5C2. 
II. CUSTOMARY LAND TENURE IN PAPUA NEW GUINEA:

A DESCRIPTIVE SKETCH OF THE STATUS QUO

(a) Introduction 7

(b) Interests in Customary Land 8

(c) Registration 10

(d) Dispute Resolution 13

(e) Alienability 13

III. THE TASKS OF REFORM 14

(a) The Relevance of Economic Analysis

to Customary Land Law Reform 14

(b) The Constraints on Rural Land Development 21

(i) Socio-cultural Attitudes and Values 21

(ii) Security of Tenure 25

(iii) Prohibition on Direct Dealings 26

(iv) Transaction Costs 27

(v) Capital $\quad 27$

(vi) Development Expertise 28

(vii) Administrative Resources $\quad 30$

(viii) How Economically Relevant Are These $\quad 30$

(ix) What Policy Weight Should be Accorded 32

IV. REFORM PROPOSALS $\quad 34$

(a) Direct Dealings in Customary Land 34

(i) A Facilitative Framework 34

(ii) Transaction Costs and Group Decision Rules 44

(b) A Customary Land Registration System 49

(i) The Interests to be Registered 56

(ii) Identification of the Land 57

(iii) Identification of the Parties 58

(iv) The Strength of Statc Support Required
For Customary Land Title Registration

(c) Conclusions $\quad 64$ 


\section{INTRODUCTION}

Papua New Guinea contains some of the oldest and most "primitive" cultures known to mankind. ${ }^{1}$ In various parts of Papua New Guinea many of these stone age cultures can be found functioning today in much the same way that they have for thousands of years. Indeed, the Highlands of Papua New Guinea, which comprise almost half of the country's population and some of its most fertile land, experienced no meaningful contact with the outside world until after the Second World War. These cultures have long attracted the scholarly interest of many of the world's most distinguished anthropologists (the work of Malinowski and Mead perhaps being amongst the most widely known) This paper will seek to highlight issues in the area of property rights that have become particularly problematic with the increasing interface of these "primitive" cultures with modern economic forces and that hold fascination for lawyers and economists as well as other disciplines.

The formal economy of Papua New Guinea prior to World War II was tiny in scale, involving principally copra and gold exports which in 1940 amounted in total to bA 4 million. Since the war the 
economy has grown rapidly in size with exports worth almost 1 billion dollars (U.S.) in 1980. Exports have diversified to include copper, coffee, rubber, tea, lumber, fish, palm oil and cocoa. About 35\% of GDP is accounted for by agriculture (with mining next at $9 \%$ ). Over a half of all agricultural exports are now accounted for by smallholder production, most of the growth in which has occurred since World War II. About $85 \%$ of the population still live in rural areas, and of the estimated total economically active population of 1,126 million people aged 15 to 64 in 1979 (out of a total population of about 3 million), only about 150,000 (13\%) were engaged in formal employment, the balance being engaged in small-holder agriculture or subsistence food production (or some combination of the two) ${ }^{2}$.

The importance of agricultural activities to the economy (formal and informal) of Papua New Guinea will be obvious from these cursory figures, as will the dramatic increase in involvement by Papua New Guineans in the cash economy. This increased involvement has typically taken the form of rapid growth in small-holder agricultural production (cash cropping), with significant secondary involvement more recently in the plantation sector. However, conservative estimates suggest that about eight times the land presently being utilized for any form of agricultural production (including subsistence) could be utilized for commercial agricultural production. Other estimates of the ratio of utilizable to utilized land go as high as 20 to 1 . The World Bank 
in a recent report on Papua New Guinea ${ }^{3}$ projects a decline in the growth rates in the agricultural sector from $3.3 \%$ p.a. in 1980 to $2 \%$ p.a. by 1990 , less than the annual population growth of $2.3 \%$, and projects further that if present policies and patterns persist, only about $10 \%$ - $20 \%$ of the roughly 250,000 net citizen additions to the labour force in the 1980s will be able to find formal employment. The balance of $80 \%-90 \%$ will be compelled to find income opportunities either in small-holder or subsistence agriculture or in the informal urban sector, despite sharply rising levels of education and concomitant expectations. Improvements in agricultural productivity and more specifically the more efficient utilization of the country's land resources are identified by the Bank as offering most of the growth possibilities for the foreseeable future. However, the Bank also notes: "The mobilization of these land resources would require major changes in land administration and legislation ... land legislation and/or administration are serious constraints on development of large-scale reforestation, agriculture and livestock projects ... Disputes over land ownership in a nation with neither the machinery nor the political will to deal with them have been a major constraint on development." 4

Any moderately alert observer of daily affairs in Papua New Guinea quickly comes to realize the preoccupation with land issues in the life of the country. Casual canvassing of local daily newspapers and other local sources over recent months (1982) disclose events such as the following: 
(a) A 20 million kina (K1=U.S. \$1.4) port development at Lae being undertaken by the Papua New Guinea Harbours Board with Asian Development Bank financing has been halted as a result of access roads for the contractors being barricaded by a local clan who claim that their traditional canoe beaching rights have been infringed by the project and who are demanding $\mathrm{K} 2.8$ million compensation; the project might well be abandoned;

(b) After the national government had recently allocated government land by way of a lease to a ready-mixed concrete company for development of a cement bulk-handling facility on the Lae waterfront, 700 squatters moved on to the land and constructed traditional houses, following a dispute with other customary land-owners from whom they previously rented land, and have defied all legal and other efforts to induce them to move; the $\mathrm{K} 3-4$ million project is in abeyance;

(c) Local land-owners have barricaded access to a log-felling and sawmilling operation in the Brown River area with respect to which the national government had previously voluntarily acquired the timber rights from the local land-owners and in turn sold them to the operator of the mill. The land-owners now claim that they were inadequately compensated by the government. The company has laid off 300 workers and may abandon the site; 
(d) The Rabaul airport cannot be opened to jet traffic because a group of local land-owners, with land alongside the airport on which coconut palms are growing which need to be cut down to improve visibility, will not agree to this unless ademand for K10 million compensation is met.

(e) Two years ago a school in the East Sepik had water cut off to it by adjoining land-owners who had previously sold the land to the government for the school (the water pipe running over land that had been retained) and who claimed $\mathrm{K} 1 / 2$ million in additional compensation;

(f) "Fighting zones" are periodically declared by governments in the Highlands (involving a prohibition on carrying traditional arms), when tribal wars break out between rural clans, typically over land disputes and often involving significant loss of life and personal injury;

(g) A drive through some rural village areas in the Highlands will sometimes lead one past a village burnt to the ground and surrounding coffee trees uprooted by a raiding neighbouring clan engaged in a land dispute with the occupants of the village; retaliation in kind will often follow;

(h) A regional land court magistrate in the Highlands told the author of a recent case where, having adjudicated a land dispute between two neighbouring clans, he went out to the disputed land to perform his statutory obligation of overseeing the marking out of the disputed boundary only to be greeted by 
two to three hundred warriors from the losing side in full traditional war dress and armed with bows and arrows, who defied him to enter onto the land. A major police convoy several weeks later was necessary to enable him to complete the boundary demarcation. In another case, the magistrate, in a similar context, went out to the disputed 1and to demarcate the boundaries to find himself very quickly caught in a cross-fire of arrows from the two opposing sides as a full-scale tribal war broke out on the spot.

(i) One of the daily newspapers in Papua New Guinea recently reported that outstanding land compensation claims against the government in Papua New Guinea amount to close to Kl billion and that promoting compensation claims is the "biggest growth industry in the country".

Attempts to define and protect property rights in customary land have pre-occupied policy-makers in Papua New Guinea over many decades. Attempts by the Australian Colonial Administration to determine and register entitlements in the 1950 s and 1960s proved almost completely unsuccessful and, as the incidents cited above suggest, further attempts since Independence in 1975 to institute a stable regime of property rights have enjoyed little more success. 
This essay attempts briefly to describe existing customary land tenure arrangements in Papua New Guinea, to identify existing constraints on economic development created by these arrangements, and to sketch a set of proposals that may enable a beginning to be made on realizing the developmental potential of customary land by enhancing the definition and stability of property rights and by permitting a more flexible range of dealings in them so that efficient utilization of land can be facilitated but in ways which are sensitive to local social and cultural norms.

II. CUSTOMARY LAND TENURE IN PAPUA NEW GUINEA: A DESCRIPTIVE SKETCH DF THE STATUS QUO

A.

(a) Introduction

Over 97 percent of the total land area (47 million hectares) in Papua New Guinea is "customary land", that is land owned under traditional or customary title by nationals. Less than three percent of the land (1.2 million hectares) has been alienated from the customary land-owners. of this three percent, a small percentage (about 125,000 hectares) comprises private freeholds, mainly held by missions and plantations. Most alienated land is owned by the government. The government owns some of this land beneficially (about 120,000 hectares) and has granted long-term (99 year) leasehold interests in the rest to other parties. 
(b) Interests in Customary Land

Generalizations about customary land-owning practices are difficult given widely varying traditions amongst the 700 tribes that make up Papua New Guinea and given limited empirical research into these practices. According to Crocombe and Hide ${ }^{5}$, different categories of rights to land are typically held at different levels. Tribes and phratries, the largest social units in Papua New Guinea, in many cases hold no land rights and those they do are few and of limited significance. At the level of the clan, parish or community, there are common rights to hunting territories and common defence obligations. Bush-fallow rotations of gardens of component sub-groups are often contained within the lands of such groups. Group land rights tend to be focussed at the level of subclans and lineages

or hamlets and villages (with membership numbering from a few dozen to a few hundred) where decisions on the allocation of land other than by inheritance are most frequently made. Rights to intensive use (e.g. gardening) are usually held at a lower level, typically the household, at least one member of which, usually the household head, is either a member of the land-owning group or has a relationship with some-one who is. Rights of extensive use e.g. grazing of animals, are often held in common at the sub-clan level.

In their detailed study of land-holding patterns and agricultural practices amongst the Chimbu of the Papua New Guinea Highlands, 
Brookfield and Brown ${ }^{6}$ found that group ownership tended to prevail with lower quality land and individual ownership with respect to 1 and that was capable of intensive cultivation - typically gardening land or more recently land suitable for cash-cropping such as coffee production. The authors point out that the relationship between individual and group rights, obligations and activities is complex. While the nuclear family is the basic economic unit, it is not fully independent. A family's food supply is derived from a number of gardens; its own, those it has borrowed, and those it shares with others on its own or borrowed 1and. Within a sub-clan parts of gardens are frequently lent in return for help in land preparation. Malinowski in his work on agricultural practices amongst the Trobriand Islanders also emphasizes the absence of a sharp distinction between individual and communal property rights.

The main principles on which land-owning groups are formed are descent, locality (or residence), and participation in common activities surh as gardening or defence. 8 Traditionally, 1 and has not been tzoatcd as a commodity that is subject to exchange, barter and sale. However, within groups land loans or gifts are common as part of the mutual aid between fellow clansmen, kin and affines. ${ }^{9}$ The inheritance of individual proprietary rights, which pass almost invariably to descendants by blood, depends on partilineal or matrilineal emphasis (which varies by locale throughout the country). 
Anthropologists have recently pointed to dangers, indeed fallacies in assumming tightly defined group structures by lineage, location or otherwise within primitive societies, including Papua New Guinea ${ }^{10}$. "Reifying" groups, it is argued, ignore their continuous and almost invisible quality and cannot clearly account for "the shadowy and insubstantial world of rights and claims moving ... between groups". 11 Specifically, in the case of land, lineage claims may apparently peter out if not actively and continuously asserted. Inter-marriage between members of different sub-clans or clans may produce overlapping group memberships. Locational presence or participation or clan activities may generate rights, at least to usage, in addition to rights possessed to other land by descent. On this view, groups rarely own property rights to land as a collectivity, but rather group membership characteristics will determine individual property rights within these group bounds.

\section{(c) Registration}

No interests in customary land are presently registered. Two abortive attempts have been made to introduce a registration system. The Native Land Registration Act 1952 established a Native Land Commission and gave it the dual tasks of systematically recording the ownership of all customary land in the country and of determining the ownership of particular plots when claimants applied to the Commission. The Commission was unable even to begin the task of systematically recording the ownership of the 183,000 square miles of land in Papua New Guinea and concentrated instead on individual 
applications for registrations. In the ten years of its operation, 472 applications were received, 176 were decided, but only a few plots were later surveyed, and none was registered. 12

The Land Titles Commission Act 1962 replaced the Native Land Commission with the Land Titles Commission, but with a very similar mandate. However, the process of systematically recording the ownership of customary land was restricted to "adjudication areas" selected by the Commission, and the Commission was to be assisted by advisory "demarcation committees", appointed by it, comprised of local land-owners and leaders. Apparently contrary to the intent of the Act, the Chief Commissioner of the Land Titles Commission in 1965 divided the whole country into 500 adjudication areas and appointed local demarcation committees for each area. The functions of these committees were never clearly defined; many never actively operated at all, others attempted to resolve disputes and rationalize the varied claims to scattered parcels by different groups - a process that often prompted further conflict as groups feared a "freezing" of current claims to use. ${ }^{13}$ Up to 1970 , no titles were registered in the Communally Owned Land Register set up following the 1962 legislation. 14 In that year the register was suspended upon the advice of a visiting land expert, Mr. S. Rowton Simpson, who saw no benefits in registration because dealings in the land could not also be registered and who was critical of the Commission's policy of accepting for registration individual claims to sole beneficial ownership of customary land. Simpson considered that these interests should be tenure converted (to conventional freeholds) and no longer considered customary land. 15 
In the wake of the Simpson Report of 1969, a package of land reform bills was tabled by the Australian Administration in the House of Assembly in June 1971. These bills contemplated geographically selective registration of interests in customary land. Group interests were to be registered in the names of representatives of groups who were given the power (but not necessarily the right) to deal with the land as if they were absolute owners. Individuals owning the sole beneficial interest in customary land would have been permitted to acquire and register full freehold interests.

These bills were withdrawn in the face of widespread objections. Some of the objections focussed on the trend towards individualization of tenure facilitated by the bills and the possibilities of aggregation of land in the hands of an elite, with "landlessness" and "landlordism" perceived as likely consequences. Other objections stressed the potential for abuse in a system of representative decision-making by small numbers of group members. 16

Following the withdrawal of the 1971 bills, the government (Papau New Guinea had become self-governing in 1972) set up the Commission of Inquiry into Land Matters (the C.I.L.M.) which reported in 1973. . The Committee's Report ranges widely over many issues of land policy, including registration of interests in customary 1 and. 


\section{(d) Dispute Resolution}

Both the Native Land Commission and the Land Titles Commission were vested with substantial dispute resolution powers, with appeals from Commission decisions to the Supreme Court. Prior to 1952, land disputes were a matter of litigation before the Supreme Court. In 1975, following recommendations of the C.I.L.M., the Land Disputes Settlement Act of that year set up a system of decentralized dispute resolution, involving informal mediation, and in the event that mediation fails, binding determination by local Land Courts, with appeals therefrom to District (now Provincial) Land Courts.

\section{(e) Alienability}

Section 81 of the Land Act of 1962-73 provides that "a native has no power to sell, lease or dispose of native land othervise than to natives in accordance with native custom. A contract of agreement made by him to do so is void". This is subject to section 16 of the Land Act which permits the government to purchase or lease customary land "if the native owners are willing to dispose of [it] otherwise than to natives in accordance with native custom". In voluntary transactions between the government and customary lanciowners, all members of a land-owing group must generally consent to a transaction. In effect, a principle of unanimity applies. The Land Act also provides for powers of compulsory acquisition over land generally, including customary 1 and, for prescribed public purposes and in accordance with prescribed procedures. 
By virtue of the Land (Tenure Conversion) Act 1963, where all members of a group of customary land-owners agree, an individual member of the group may apply to the Land Titles Commission for registration of an individual freehold title to the land. Up to six individuals may be registered as joint tenants or tenants in common. Following registration, the registered proprietor is competent to deal with the land in the same way and to the same extent as any other registered proprietor of a freehold interest, with certain qualifications: land may only be sold or leased to automatic citizens or the government; land may only be mortgaged subject to the limitations that the mortgagee is not entitled to remain in possession for longer than three years or to foreclose the mortgagor's right of redemption; " land may not be taken under a writ of execution or pursuant to bankruptcy proceedings.

Fewer than a thousand conversion orders have been made under the Act. Administrative activities under the Act were reduced following adverse recommendations in the C.I.L.M.'s report, but in the absence of legislative implementation of the relevant recommendations, applications for tenure conversions are again being processed in small numbers.

III. THE TASKS OF REFORM

(a) The Relevance of Economic Analysis to Customary Land Law Reform

Land, of course, occupies an enormously complex economic, social, cultural, and religious role in Papua New Guinea. The unique characteristics of land in traditional Papua New Guinean society are well captured in the following statement by Burton-Bradley (a psychologist) $:^{18}$ 
"In the course of my work in Papua Neli Guinea, I have become aware that the indigenous person has a psychological attachment to his land transcending the purely economic and legal arrangements of the superimposed alien culture, however liberal the latter might be. I find that he may go along with the formal arrangements in order to please, but in his thinking and at a deeper level his basic attitude to what is his land remains substantially unchanged throughout life, independent of any transactions and exchanges which have taken place. His land is the place where he was born, where he was subjected to primary enculturation, where he has lived the most important aspects of his 1 ife, where the values of his cultural-linguistic group have been constantly reinforced, and where, in most instances, he may die. As he grows up he learns that it is the place where his ancestors preceded him, and to which they may return, thus giving the attachment a magico-religious sanction. It is the place where his children and his children's children will follow. At the psychological level it is clearly an extension of the concept of self."

A major implication often drawn from this vieli of land is that the concept of land as merely a factor of production in economic activity is entirely foreign to a traditional culture and that legal institutions should recognize this fact. Thus, a system of individualized land tenure and freedom of alienability are often perceived as inappropriate legal institutions in a culture viewing land in the way described by Burton-Bradley.

This view of customary 1 and tenure arrangements in a culture such as Papua New Guinea has recently been challenged in theorizing on economic anthropology. In particular, Professor Richard Posner has argued ${ }^{19}$ that the social institutions that one commonly observes in 
tratitional, pre-literate societies were (are) economically rational, given certain assumptions, in particular the high costs of information in a pre-literate society. Non-literacy prevented the formation of an effective government. Without an effective government, there could not be any effective mechanism for the enforcement of contracts. Without an effective system of contact enforcement, and in the absence of information networks predicated on literacy, individuals had to confine their interactions to members of a stable group with whom they were c.losely familiar. Hence the emergence of kinship groups or clans. Within such groups, elaborate sets of reciprocal obligations emerged. Posner characterizes this complex of obligations as an informal "mutual insurance company". These groups were typically larger than the family because this permitted greater diversification of risk e.g. reduced the covariance in the food production of the individual members, but constraints on the size of kinship groups or clans were imposed by the high costs of information and lack of effective law enforcement.

The important implication of Posner's theory is that many institutions which one observes in traditional socieites were attributable to a lack of alternative "insurance" mechanisms (broadly conceived). These alternatives in a modern society take various forms: as individuals gain access to a wider range of markets through improved information networks and legal enforcement of contracts, self-insurance becomes more feasible through diversification of economic activities. For similar reasons, explicit 
private insurance arrangements are likely in turn to evolve. As effective government evolves, collective "insurance" arrangements become possible in the form of social security programmes, such as state medical services or pension schemes.

Posner's theorizing leaves some important questions unanswered. First, the behavioural imperative that seems to drive his economic model is security maximization (which he seems implicitly to equate with economic rationality) rather than profit or wealth maximization (which in other contexts he has equated with economic rationality and indeed normative precepts of justice). ${ }^{20}$ A society that espouses the goal of maximizing economic security is likely to be a relatively egalitarian society, while a society that espouses the goal of maximizing profits or wealth is likely to be a relatively unegalitarian society. How or why some societies evolve from the one to the other is not satisfactorily explained by Posner.

A related problem with his theory is that if all societies throughout history have tended to adopt "economically rational" institutions given their circumstances, the process of economic evolution becomes difficult to explain. If all societies were throughout time as economically

rational as Posner says they were, why would they not from the outset have invented literacy and effective government, which according to Posner's own argument are, or lead to, more efficient social institutions than those that one cunmon!y observes in traditional societies? In other 
words, how does not account for different rates and directions of development? In this respect, it is clearly tenuous to rely unduly on theories of historical determinism. 2 It is simply not the case that as societies have modernized, there is an inexorable movement along a continuum towards private ownership and alienability of property rights enforced by the State. Indeed, about half of the modern world seems to have gravitated in the opposite direction towards highly collectivistic concepts of property rights. However, these difficulties aside, Posner offers the important insight that many institutions in traditional societies serve, at least in part, an insurance or security function in the absence of effective alternatives. But, crucially, as substitutes evolve, we would expect to observe reduced reliance on traditional "insurance" or security arrangements, although the patterns of substitution that will occur are much less easy to predict.

What has all this to do with reform of land tenure arrangements in Papua New Guinea? Viewing customary (or communal) land tenure as, at least in part, a form of insurance or social security leads one to accept that in a rapidly evolving society with increasing exposure to the money economy, growing literacy, greater mobility, and more effective government, the relative roles of alternative forms of "insurance" (or social security) will also continue to evolve. More specifically, one would expect to see, over time, reduced reliance on traditional "insurance" institutions, such as customary (or communal) land tenure, as feasible, and perhaps preferred. 
alternatives begin to emerge. The ultimate relationship between customary kinship ties, explicit market arrangements, and government is impossible to predict in this context. A permanent equilibrium may never be reached. Thus, if one views land tenure reform in this broader perspective, looking for a "final" solution to land tenure problems in Papua New Guinea may be like looking for the Holy Grail. It does not exist.

Recognizing this, the policy goal may be both to facilitate processes of evolution and transition while, at the same time, (as economic historians like Polanyi ${ }^{22}$.. would no doubt argue) imposing some broad constraints on those processes so that social and personal dislocation and attendant social costs from change are kept to acceptable bounds. Many Papua New Guineans find themselves experiencing in a few decades processes of human evolution and development that in many developed societies occurred over many hundreds, if not thousands, of years. Moving from traditional tribal communities into a full-hlown mokicrn cconomy within a fow generations involves awesome changes in social structures, lifestyles, belief systems and expectations. Whether the social costs associated with these changes are best managed by slowing the process of change or by facilitating rapid movement through the development threshold appears to be a matter of controversy in the anthropological 1iterature. For example, Margaret Mead in her early 
writing on Papua New Guinea lamented the disappearance of many

primitive societies - "obliterated by firearms or alcohol, evangelism

or tuberculosis"' ending diverse experiments with "the possibilities

of the human spirit". On the other hand, in her book, New Lives

For $01 \mathrm{~d},{ }^{24}$ recounting her impressions of Manus Island twenty-five

years after her earlier work and after Manus islanders had been

exposed to a massive infusion of troops during World War II, she

expressed serious doubts about the conventional anthropological wisdom:

"One important contribution of this record of change among the Manus is that it points up the completeness with which a people may want to change rather than merely submit to being changed; it shows culture contact as an active choice of the emigrants from the Stone Age as it is for representatives of highly industrialized countries and it points up the "resistance" to giving in the members of the more developed "culture" as well as the resistance to receiving in the members of the "under-developed culture"... How often has our Western attempt to preserve native dress, old customs, different styles of architecture, to respect native laws and customs, been only a thin disguise over an unwillingness to admit a people newly entering into our way of life, to a full participation in the culture which we claim to value so highly? ... Partial change can be seen not as a bridge between old and new, something that permits men, slow to learn and fumbling at the unfamiliar, some respite from the unbearableness of change but rather as the condition within which discordant and discrepant institutions and practices develop and proliferate with corresponding discrepancies and discordancies in the lives of those who live within them." 
How the process of change should be managed, specifically in the present context with respect to land reform, is obviously a major threshold question for Papua New Guineans policy-makers and can only be resolved in the context of a much broader conceptualization of a strategy of economic and social development. Whatever the constraints on the process of change that are considered appropirate, it seems unlikely that they will be invariant over time, but will be the subject of constant adjustments as social preferences as to the appropriate roles of kinship ties, explicit markets, and formal government in the lives of Papua New Guineans are shaped and re-shaped by the course of the country's history. It is against this broad backdrop that some quite specific and immediate issues of land tenure reform are canvassed in this paper.

\section{(b) The Constraints on Rural Land Development}

(i) Socio-cultural Attitudes and Values

As described by Burton-Bradley, traditional attitudes to land preclude it being viewed simply and exclusively as an economic factor of production that can be owned and traded "commodified" in Polanyi's terms) ${ }^{25}$ like any other economic resnurce. The specific constraints that seem to be implied by these attitudes are that much land is not individually but communally owned and that the current generation of owners have no more than, in effect, a life interest in their land with similar 
interests over time accruing to future generations of the landowning groups. Proponents of customary land reform in developing countries who argue for individualization of property rights and wide freedom of alienability typically point to the efficiency gains likely to be associated with such reforms. For example, Healy, in describing sweeping (and in economic terms, apparently quite successful) post World War II land reforms in Kenya directed to these objectives, and in endorsing the later views of Mead on the adaptability to rapid change of a traditional culture, states that "basically [the reforms] depended on the realization that individual incentive is the key to better farming, to higher living standards and to nation-wide economic progress". The ideological premises underlying this assertion are made quite explicit:

"Most of the under-developed parts of the world have been primarily influenced by Western European values despite currently socialistic policies - and individual or family improvement may be taken as one of the prime desiderata governing conduct and concepts. Indeed, it is well recognized that as the economy develops and opportunities open up for the indigenous peoples, the kinship framework tends to shrink - especially in the sphere of obligations ... It is reasonable to assume that the individual or family-unit form of title will accord most closely with what will be desired as Western notions of economic individualism permeate society".

However, whatever the efficiency gains from individualization of tenure and freedom of alienation, other important social values are also implicated. Moreover, the thesis that there is a natural historical evolution from communal to individualized property rights 
in land, while propounded by eminent historians like Sir Henry Mainc 28 has not gone unchallenged; the evidence seems far from conclusive. 29

The social costs perceived by many Papua New Guineans as attendant on any moves towards individualized tenure and outright alienability are that some members of both the current generation and future generations of land-owning groups may be deprived of the security "net" in effect provided by the opportunity and indeed right always to look to their land as a source of subsistence, and the social netiork of reciprocal obligations associated with land, in the event that income-earning opportunities else-where in the economy cannot be realized. 30 It might be argued, of course, that if kinship ties amongst members of land-owning groups are close enough, individual members of these groups, in the event that individualized tenure and outright alienability were to be permitted, would fully incorporate the interests of other members of the kinship group, present and future, into their decision calculi. However, many of these groups are large, rather amorphous, and ill-defined, and the assumption that individuals would act so as to maximize the interests of all members of the group, present and future, seems a precarious one. It might alternatively be argued that if, under a system of individualized land tenure and 
outright alienability, major efficiency gains are likely to be realized, redistributive possibilities are increased not reduced with growth in the size of the economic pie. However, there is no guarantee that the State will choose to redistribute some of the individual gains from more efficient utilization of land to other members of the kinship group, so that these possibilities may be seen as inadequate substitutes for the wealth pooling implicit in present property rights arrangements. Moreover, even if these redistributive possibilities could be realized by members of kinship groups there will still be concerns over the social costs associated with increasing specialization of land ownership and utilization in terms of impacts on traditional lifestyles and cultural and religious values that are in large part a function of generalized community involvement in land-based activities. These transitional costs may be quite severe e.g. urban "drift", high levels of urban unemployment, and serious urban $1 \mathrm{aw}$ and order problems. ${ }^{31}$ It might be added here that individualization of tenure and freedom of alienation are not alone in their potential for dislocation of traditional social structures. Evidence seems to suggest that various forms of induced collectivization e.g. State farms, peasant communes, may have equally traumatic impacts on such structures. 32 


\section{(ii) Security of Tenure}

Even where development is desired by customary landowners the absence of any documentary system of title or registry of interests in customary land, coupled with difficulties of developing and enforcing an effective dispute resolution regime, create substantial insecurity of tenure and disincentives to development. As 1 and assumes increased economic value as a source of income generation in the money economy and as population growth further increases its scarcity value, it can be predicted that the potential for land disputes (already pervasive in Papua New Guinea and today the cause of frequent tribal wars) will increase, reflecting the economic value attached to assertions of property rights. As Demsetz has argued, 33 with reference to anthropological studies of North American Indian tribes, the movement towards clearer and more exclusive delineation of property rights amongst tribes or members of them seems in large part to have been prompted by a change in the function of hunting from the provision of food to income generation through participation in the fur trade. This change in function rendered it economically more important that the costs and benefits of land utilization be concentrated in relatively small and discrete groups of land-owners. The more extreme forms of communal land ownership permit some landowners to impose costs on others or permit some land-owners to reap benefits from the efforts of others, both of which possibilities create externalities that discourage efficient utilization of 1 and. 


\section{(iii) Prohibition on Direct Dealings}

The Lands Act 1962 effectively establishes the government as the only party who can acquire land from customary landowners and prohibits direct alienation by customary landowners of their land to parties outside the landowning group.

This intermediation role of government raises several problems. First, the administrative machinery through which transactions must be processed is very intensive in bureaucratic resources and is extremely slow and inefficient; delays of two or three years before a transaction can be consummated are the rule and longer delays are commonplace. Second, many customary landowners appear to resent being compelled to deal with the government (effectively a monopsonist) and consider that they could advance their interests more effectively by being able to canvass opportunities directly with a range of third parties. As opportunities for development increase in nature and number with the increasing monetization of the economy, it can be predicted that pressures for some form of direct acquisition and alientation will mount. Unless ways can be found for facilitating the movement of land from lower to higher valued uses and mitigating the static qualities of present arrangements, the system will not foster the dynamism required to take up many of these opportunities. 


\section{(iv) Transaction Costs}

The rule of unanimity which appears to prevail in most customary landowner groups with respect to decisions affecting communal 1 and, even in voluntary transactions with government, generates substantial transaction costs in concluding and maintaining agreements where often hundreds of individual consents from all the members of a clan must be obtained before a transaction can be concluded or varied. The absence of a hereditary chieftain system in most parts of the country - "big men" whose influence is a function of popular support come closest to performing the role of tribal leaders - lends force to such a rule. Moreover, it can be predicted that increased population mobility reflecting higher levels of education, improved transportion infrastructures, increased opportunities to participate in the development of the country, inter-marriage, etc., will render composition of landowning groups less stable than in the past, thus further increasing the transaction costs involved in securing necessary consents to transactions. Again, as Demsetz points out, 34 those transaction costs are one of the most serious sources of inefficiency in more extreme forms of communal property rights regimes.

\section{(v) Capital}

Customary landowning groups, even where they possess land with substantial agricultural development potential, will rarely possess 
financial resources of their own to undertake major development of their 1and. Inability to offer their land readily as security to sources of loan financing or to involve joint venturers with equity capital is thus a particularly pressing constraint.

\section{(vi) Development Expertise}

Customary landowners in rural areas often have very little conception about what "development" or "bisnis" involves beyond generally being ostensibly in favour of it. More concerted educational efforts are required to acquaint landowners with the full implications (positive and negative) of alternative development possibilities so that realistic expectations are formed and disappointments and surprises avoided. Once a project has been embarked upon, frequently highly applied forms of technical and managerial assistance will be required to develop the project and to provide on-the-job training to local landowners and employees. In the case of smallholder development, concerns have been widely expressed in recent reviews of agricultural development policy in Papua New Guinea that extension services, now decentralized to the 19 provincial governments recently created in Papua New Guinea, are currently operating at a very low level of effectiveness. In the case of larger-scale agricultural developments, only the State-owned National P1antation Management Agency (N.P.M.A.) and a handful of private management advisory firms provide sources of management expertise. 
In the case of the N.P.M.A. the availability of the agency's services have until now been largely confined to providing management expertise to national groups which acquired plantations from expatriate owners under the Plantation Redistribution Scheme (introduced following Independence but now suspended).

Clearly, in order for substantial progress to be made in facilitating the development of customary land in rural areas (if such be an agreed policy goal), the policy framework needs to ensure that each of the three key inputs - land, capital, and education/expertise can be provided in an efficient and coordinated fashion. In developing the proposals in the remainder of this essay, I attempt to bear this overriding goal in mind, specifically by attempting to fashion proposals that offer, to the greatest extent possible, "one-stop service" for customary landowners interested in developing their land but needing assistance in resolving legal issues pertaining to their security of tenure on the land, obtaining capital, and requiring expert management assistance. A bureaucratic structure that confronts rural people, untutored in the ways of modern government, with complexities and delays across numerous and often remote agencies or units of the bureaucracy, each of which must be separately dealt with in respect to these various inputs, is likely to provide a major source of discouragement to development. 
(vii) Administrative Resources

The government of Papua New Guinea lacks both the financial

resources and technical expertise to embark upon a complex, resourceintensive set of customary land law reforms, and proposals for reform must accept this as a real and substantial constraint by minimizing the demands on such resources. At present, it can be argued that there is a serious misallocation of these scarce resources: most land administration resources are directed to the $3 \%$ of 1 and in Papua. New Guinea that has been alienated and very few resources directed to the $97 \%$ of the land that is customarily owned.

(viii) How Economically Relevant Are These Constraints? Despite the impact of these constraints, it might be argued that they do not individually or collectively fully explain the nonutilization of utilizable land in Papua New Guinea. Assessments of the latter, it can reasonably be argued, relate to technological rather than economic feasibility. Given the already substantial increases in small-holder production, what economic or other factors explain why it is not rapidly absorbing all unutilized land. If the marginal cost of a land-owning group placing additional land that it owns under production is zero, holding all other cost factors constant, one would expect to observe additional land being utilized until its marginal product was zero. If all other cost factors are not held constant, 
it might still be argued that the unemployed or underemployed labour conventionally assumed to exist in the rural sectors of many developing countries will still make it worthwhile to place an increasing amount of land under commercial production as long as the yields cover. the marginal cost of labour, regardless of whether greater yields could be realized with different inputs of labour or capital (which the constraints noted above may affect).

The fact that development has not spread to all utilizable land despite these considerations may lead one to several possible hypotheses: one might be that land-owners in their present stage of transition from a subsistence society are "satisficers" rather than "maximizers" and are content to realize very modest cash incomes. Another might be that customary intra-group rules constrain individual or group initiatives in various ways e.g. by requiring a sharing of wealth within a group, irrespective of varying contributions to the creation of this wealth - a free rider problem that may create severe disincentives to maximizing production and that may be largely unaffected by removal or reduction of the other constraints noted above. Another hypothesis may suggest that the limited incursions of smal1-holder agriculture reflect a relatively straightforward form of economic rationality. The marginal cost of rural labour may not in 
fact be close to zero. Minimum wage laws have forced up the cost of employed labour significantly, while the relative success at the small-holder level of less labour intensive crops (e.g. coffee) compared to the relative failure of more labour intensive crops (tea, pyrethrum, rice) suggests that land-owners do not see the opportunity cost of their own labour as zero (perhaps to be explained in terms of labour-leisure trade-offs, given readily available means of subsistence). 35 This in turn would suggest notential economic returns from substituting capital for labour in larger-scale forms of agricultural production at least with respect to certain crops where prevailing levels of returns cannot cover the opportunity cost of labour in small-holder production. In order to facilitate these substitution possibilities, removing or reducing the constraints noted above once again becomes important.

(ix) What Policy Weight Should be Accorded to the Non-Economic Constraints?

With respect to the first constraint on customary land development noted above i.e. socio-cultural attitudes and values, the proposals developed in this paper attempt to respect these attitudes and values in various ways:

(1) By continuing the prohibition on outright alienation of customary land, except to the government, and instead providing for a system of direct creation of 
limited leasehold (usufructuary) and security interests in customary land, thus protecting future generations of the land-owning groups byensuring that the land will always revert eventually to the group. Reversibility in policy-making is also enhanced by this approach in the event that undesirable consequences are perceived over time to be induced by these proposals.

(2) By continuing to emphasize the concept of a form of communal rather than individual ownership of customary land, so that the benefits of development are widely distributed, although subject to some proposals designed to reduce the transaction costs involved in group decisionmaking by permitting forms of representative decisionmaking.

(3) By not compelling any group which does not want to do anything with its land to do anything against its wishes. Thus "sporadic" rather than "systematic" registration of interests in customary land is proposed so that only land-owners wishing to develop their land in circumstances where security of title is important need avail themselves of the system.

These proposals are now developed in more detail. 
IV. REFORM PROPOSALS

(a) Direct Dealings in Customary Land

(i) A Facilitative Framework

As previously noted, direct dealings, otherwise than in accordance with custom, between customary land-owners and third partners, other than the government, are generally prohibited. In voluntary transactions between the government and cutomary land-owners, all members of a landowning group must generally consent to a transaction. In effect a principle of unanimity applies.

In fact, customary land laws in many parts of the country from time immemorial have permitted the consensual creation of interests in customary land. These may have involved the creation of squatter's rights in favour of migrants from other parts of the country, the creation of various occupational or usage rights such as fishing rights, hunting rights, wood or berry gathering rights, rights to traverse, etc. It is important to stress this, because sometimes the impression is given that customary land law is extremely rigid and inflexible in terms of the recognition of these consensually created rights.

Ward, in a recent paper ${ }^{36}$ describes a rapid growth in informal and often non-customary dealings in customary land, including clan land usage 
agreements permitting an individual member of a clan exclusive use of given land for agricultural production for a certain period of time; group projects involving inter-clan agreements as to common working and development of both groups' lands; leasing and outright sale of land, often to "migrants" from other regions of the country; contrived disputes under the Land Disputes Settlement Act designed to produce binding declarations of title to land in order to facilitate development projects; and unofficial transfers of government leasehold interests in land settlement schemes. Ward concludes "that there is widespread popular support for direct dealing, and the C.I.L.M.'s attempt to uphold a nearmonopoly for the government is breaking down, as straight commercial transactions are elaborated under the guise of 'customary' dealings."

Part of the explanation for the growth in non-customary, direct dealings (of dubious legality) in customary land appears to be a chronic inability on the part of the Department of Lands to develop flexible and expeditious procedures to govern the intermediation role assigned to the central government by the existing provisions of the Land Act. These provisions essentially require any party seeking to acquire an interest in customary land to approach the central government through the offices of the Department of Lands to buy or lease the land from the customary owners and then in turn lease it to the party interested. In some cases, this party may be the customary landowners themselves or some sub-set of them who, in the absence of a registerable government leasehold interest, have no 
ability to offer their land as security in the event that they require financing for development purposes. Severe bottlenecks in the system are reflected in the fact that an estimated 8,000 to 10,000 lease applications are now stalled in the Department of Lands. Ward's view seems persuasive that the rate and spread of economic development and opportunities in Papua New Guinea are likely to be such that the present prohibition on direct dealings in customary land will prove increasingly untenable.

However, recognizing the very special status of land in Papua New Guinean society, it appears to be widely accepted as essential, at the present time, to maintain the prohibition on absolute alienation of interests in customary land, other than to the Government. What present circumstances appear to require is the injection of some greater degree of flexibility into the existing system so as to permit and regularize the kinds of informal dealings in customary land that are already taking place on an increasing scale. It seems important that essentially two classes of transactions should be accommodated: first, agreements creating occupational and usage rights in land of some prescribed maximum duration; second, agreements facilitating the loan of funds against the security of land, subject to a restriction (similar to but more liberal than provisions already found in the Land Tenure Conversion Act.) prohibiting a mortgagee, on default by the mortgagor, from foreclosing on, or selling, the land against which security has been taken, but rather 
limiting it or an assignee or agent to working the land for some prescribed maximum period of time (e.g. ten years) by way of liquidating debts outstanding. By facilitating both direct mortgaging and direct leasing of interests in customary land, the slender trickle of rural credit presently being provided to customary landowners should be significantly augmented both in the form of secured loan financing and in the form of equity development capital provided under leasehold or joint venture arrangements.

If these classes of direct dealings in customary land are to be permitted, it is crucial that the interests of customary landowners, both present and future, be adequately protected through appropriate legal or administrative oversight mechanisms.

Criteria that might be brought to bear on proposed leasehold dealings of any significant scale in this review process might take the following form:

(1) No lease should normally exceed $X$ years (e.g. 30 years) in length (long enough to make investments in most cropping activities viable].

(2) Where the customary landowners are guaranteed significant participation in the project planned for the leased land (e.g. employment, training, joint ventureship), a lease of up to $Y$ years (e.g. 50 years) may be granted. 
(3) Where a lease is being granted to a public authority (e.g. any level of government) for public purposes (e.g. schools, police stations), a lease may be granted for up to $Y$ years.

(4) No lease should be approved if the terms do not reflect a reasonable return to the customary landowners.

(5) No lease should be approved if it would create a serious risk that the remaining land of the customary landowners may prove inadequate for subsistence food production.

(6) Lease agreements should clearly specify the lessee's maintenance and improvement obligations and compensation or other arrangements for the disposition of improvements on the termination of the lease.

(7) No lease should be approved unless the applicant for approval can demonstrate that the agreement reflects the consent of those authorized to act by the decision-rule applicable to the group of customary owners in questions and that no undue oppression of minorities has occurred.

Several concerns motivate these criteria. First, an attempt is made, by limiting the terms of leases, to restrict the abilility of present landowners to bind the next generation. This restriction comes, of course, 
at a cost. Investments involving major capital expenditures and long pay-off periods will be discouraged, although it would still be open to the government, under prevailing procedures (with all their weaknesses), to buy land outright from customary landowners and lease it on longer, renewable, terms to third party investors. Second, the criteria attempt to respect concerns over endangering the ability of customary landowners to sustain themselves by subsistence food production. This restriction also comes at a cost in that it is inconsistent with notions of the gains from specialization (it is not efficient for everybody to produce their own food), but the substantial surplus of utilizable land suggests that this is unlikely to be a serious constraint for the foreseeable future. Third, the issue of land maintenance and improvement presents some difficult problems. Without clearly specified obligations in these respects medium term leases create obvious incentives for lessees to over-utilize the land and to run down improvements as the lease term runs out. Even with well-specified obligations there are clear difficulties in the way of unsophisticated customary landowners monitoring and enforcing effectively performance of these obligations. In the case of improvements, an obligation on the part of the landowning group to compensate a lessee for improvements on the termination of the lease may often force renewal of the lease by succeeding generations and thus de facto create a form of outright alienation - to their detriment if other land uses are desired. On the other hand, to reduce lease rentals to current landowners so that improvements are compensated for over time will reduce incentives for. current landowners to enter into leases when the benefit of improvements 
will accrue gratis to future generations. Thus, the treatment of improvements will raise some complex problems of inter-generational equity.

Administering these criteria will not be an easy task. In designing an appropriate oversight agency, one possibility may be a redesigned mandate and a set of functions for the National Plantation Management Agency (presently a Crown corporation) which, as noted above, began its life as an integral institutional component of the Plantation Redistribution Scheme (now suspended) but has recently broadened its activities to include management of plantations acquired by nationals outside the Scheme and management of 20 hectare coffee blocks currently being developed with financing from the government-owned Development Bank on a lease, leaseback and mortgage basis. The N.P.M.A. is apparently about to be made a direct responsibility of the Development Bank.

As reconstituted (and renamed e.g. "The National Rural Land Development Agency"), the N.P.M.A. could usefully perform several functions -

(1) Identifying specific opportunities for rural development, presenting and explaining the implications of these to customary landowners with suitable land, and assisting with the mobilization of members of landowning groups to 
secure group endorsement of a project. This catalytic role might most acceptably be performed within a broad set of national and regional economic development priorities established by national and provincial governments and constituted as the mandate of the Agency.

(2) Vetting all significant leasehold transactions with third parties to ensure that transactions have been properly assented to and that their terms are fair to the customary landowners. Failure to secure the approval of the agency would mean that the transaction is not binding on the parties. Mortgages would not be subject to this review process, given the limited number of financial institutions in this field and concomitant ease of monitoring of their activities.

(3) Assisting in the securing of necessary finance and managerial and technical expertise from sources such as the Development Bank (with which the agency will be closely associated), private financial institutions, or private joint-venturers.

(4) Assisting customary landowners to take whatever legal steps are necessary to ensure security of tenure to their land as a basis for entering into leasehold or security transactions with third parties and to incorporate as land groups where appropriate (these proposed procedures are detailed in a later section of the paper). 
(5) Assisting landowners in monitoring and enforcing leasehold obligations of lessees.

Under the scheme proposed, quite large-scale agricultural development projects on customary land would seem feasible. This seems indicated by some precedentsialready in Papua New Guinea. For example, some largescale cattle projects have involved customary landowners indirectly leasing (through the government) large blocks of land to a company in which they are the shareholders, with the company mortgaging its leasehold interest to the Development Bank to secure development financing and the company entering into a management contract with a management expert to develop the project and train local managers who will ultimately be capable of managing the ranch on behalf of the group. Such projects also provide significant employment to members of the landowning group. With some imagination and initiative, a whole range of possible arrangements may prove attractive. It may be possible to formulate arrangements where customary landowners derive a range of different benefits from a project e.g.:

(1) lease rentals

(2) dividends from shareholdings

(3) preferred employment

(4) representation on boards of director

(5) managerial and technical on-the-job training.

Joint ventures between private suppliers of capital and managerial expertise and customary landowners should be possible whereby shares are held in proportion to land and capital contributed, with the local landowners perhaps buying down the joint venturer's shareholding over time out of dividends. 
Highly participatory arrangements of this kind have the advantage over outright alienation or passive leasing of giving the customary landowners an ongoing stake and active role in the project and less incentive to develop second thoughts about the adequacy of payments received for their land which may lead to attempts to subvert or compromise a successful project to secure redress for their grievances. This will remain a problem under the above proposals in the case of mortgages. In the event of default by customary landowners, whatever the law may say about a mortgagee's right to enforce his security, it is not clear how easy it will be to enforce these rights against a large group of disaffected and probably hostile landowners. In the case of leases, while the same possibility of default by landowners in financial obligations does not exist there may be similar incentives to subvert a lease after the lessee has invested resources in developing the land and has moved into the phase of obtaining returns from this investment. If the costs of repudiation to the landowners are not merely loss of rental payments but other benefits from participation in the project, as in active joint-venture type arrangements, these incentives may be reduced. However, in the final analysis, no system of property rights can survive without a willingness and an ability on the part of the State (or the parties) to enforce those rights.

I now turn to the question of how one right facilitate decisionmaking within land-owning groups in order to reduce the transactions costs and delays engendered by present decision rules. 


\section{(ii) Transaction Costs and Croup Decision Rules}

As has been pointed out above, present custom appears to require unanimity with respect both to dealings in customary land in accordance with established custom and in voluntary transactions with the Government. This requirement already imposes substantial transaction costs both on groups themselves and on parties seeking to deal with them. As landowning groups become less stable and more fluid because of greater population mobility, inter-marriage, etc. these transaction costs are likely to become even more severe in scale in the future. One of the major arguments for individualizing land tenure is to reduce these costs. However, the importance of individualization of land tenure to enhanced economic productivity can be exaggerated. "First, as has been the experience in a number of developing countries, individualization of property rights in land may generate impediments to efficient utilization because of extreme fragmentation of entitlements (often exacerbated by traditional concepts of succession). To reduce these costs then necessitates sweeping reforms to the customary law of succession, governmentsponsored consolidation programmes, and pressure for absolute alienability. Moreover, even in developed economies, most major economic resources are owned by groups, whether corporations, co-operatives, insurance companies, pension funds, mutual funds, or the State through public enterprises, etc. The major difference between concepts of group ownership of land resources in Papua New Guinea and concepts of group ownership in more developed economies relates to the alienability of ownership interests. In the case of corporations owning land in such an economy, alienation typically is permitted at two levels. First, the 
corporation, following a decision to this effect by its appropriate decisionmaking organs, may sell its land. Second, shareholders owning shares in the corporation may sell their shares. In the case of communally-owned land in Papua New Guinea, neither the group as a separate legal entity may as a general rule sell its land (except to the government), nor may individual members of the group as a general rule sell their interests in the group to people outside the group.

These restrictions on alienability are likely to impose substantial constraints on resources being mobilized or used in more productive ways, i.e., resources will be denied to parties who are willing to pay more for them because they are able to use them more efficiently. Here again, to the extent that this last implication is true, we are likely to face major trade-offs in policy objectives - enhanced economic efficiency, on the one hand, and various social objectives such as the maintenance of traditional ways of life and an egalitarian distribution of wealth on the other.

While preserving the concept of communal ownership, there may be room for consideration of a less exacting decision rule that permits group decisions to be taken with respect to direct dealings in customary land of the limited kind envisaged above in accordance with some form of majority or representative decision rule. Demsetz 37 argues that the division of decision-making functions in the modern publicly-held corporation provides the most notable example of the minimization of transaction costs in private, large-group ownership 
of property rights. It will be argued, of course, that a rule of unanimity promotes maximum individual participation in group decisions, protects individual rights, and respects a discussion and consensus approach to decision-making that is central to sany of Papua New Guinea's most established cultural traditions. As Hirshman points out, 38 economists tend too readily to view participation in decision-making as a cost while the behaviour of large segments of the population (e.g. the act of voting, participating in demonstrations) seems only readily explicable on the basis that it is perceived as a benefit. However, both national and provincial governments are now elected on representative principles which seem to enjoy reasonably wide public acceptance. Moreover, a rule of unanimity creates dangers of its own form of tyranny - tyranny by minorities of majorities when hold-outs see potential, and arguably unfair, gains to themselves from engaging in strategic behaviour. Both the Lands Groups Incorporation Act 1974 and the Business Groups Incorporation Act 1974 provide partial. precedents for less exacting decision rules in that mechanisms are provided by which a group can incorporate itself; subject to administrative approval, and adopt a constitution which permits representative decision-making by an elected committee whose decisions bind the group they represent. However, in the case of the Land Groups Incorporation Act, dealings in customary land, otherwise than in accordance with custom, are not at present permitted by an incorporated land group. 
The C.I.L.M. recommended that, in general, agreements which customary landowners are permitted to enter into should be endorsed by a majority of group members (whether incorporated or not). Group membership is widely defined to include children, absentees, etc. 39

Several issues fall to be resolved in this context. First, should incorporation be required as a pre-requisite to direct dealings (i.e. leases, joint ventures, security agreements, above some specified financial or other threshold) in order to provide more structure to land-owning groups both in their dealings with third parties and in their internal functioning (especially with respect to the distribution of group returns)? Second, what decision-rule should apply to the decision to incorporate a group as a prelude to direct dealing, to the election of a committee of representatives, and to decisions taken. thereafter by the group? Third, to what extent should third parties be at risk with respect to internal irregularities in group decision-making? Some tentative thoughts are offered on these questions.

First, in the interests of determinate decision-making there would seem to be a case for defining group membership less widely than proposed by the C.I.L.M. so as to include only resident adults (18 years old and above) and short-term adult absentees. Second, the decision to incorporate a land group should be made by a substantial 
consensus of group members (e.g. a two-thirds majority) as should the election of the committee of representatives. Third, for day-to-day decision-making, the committee would have authority to bind the group. Fourth, with respect to initial decisions respecting direct dealings, the committee could be required to convene a meeting of qualified group members to consider the proposal and obtain a substantial consensus approving the transaction. Statutory penalties would be incurred by group representatives who fail to respect the requirement of majority approval, but following the example of provisions in the New Zealand Maori Affairs Act 1953 (Part XXII) governing Maori land corporations, third parties who have entered into dealings with the group would not be prejudiced by internal irregularities in group decision-making of which they lacked notice. Fifth, as presently provided by the Land Groups Incorporations Act, the constitution of a group should provide an internal dispute resolution mechanism (now entailing the identification of a person as a "disputes authority") so that internal disputes over e.g. the distribution of group returns, can be resolved in an orderly and acceptable fashion. Sixth, incorporation probably should be required as a pre-requisite to significant direct dealings by groups. The Land Groups Incorporation Act would thus require amendment to permit specified classes of non-customary direct dealings by incorporated land groups. 
(b) A Custcinary Land Registration Systen

The principal rationale for a system of registration of interests in customary land in Papua New Guinea revolves around the need to reduce uncertainty and therefore risk associated with economic activities involving land where, in the absence of a registration system, lack of security of interest will discourage productive activities. These productive activities may involve local customary land-owners seeking to embark upon some course of development of their own land. The activities may involve plans on the part of customary landowners to enter into arrangements with neighbouring land-owners to pool resources, work their land in common, and realize economies of scale and specialisation. The activities may involve arrangements with non-customary third parties that might take a variety of forms: lending and security arrangements, joint venture arrangements with non-customary third parties, occupational and usage arrangements with non-customary third parties. In the absence of security of ownership interests, customary land-owners will feel less inclined to develop their own land if they face the risk of subsequent adverse claims by other parties. Similarly, arrangements with neighbouring land-owners to work land in common will be less easy to consummate if substantial risks attach to one of the groups being able to sustain either legally or practically its ownership claims to some portion of the land. Lenders seeking security against land will be less inclined to lend, or will be only inclined to lend on more stringent terms, if 
their security interest is precarious. Non-custonary third parties who might be prepared to negotiate occupational or usage arrangements with customary land-owners will equally be less inclined to enter into such arrangement, or at least on terms as favourable to the customary landowners, if the interest they obtain under these arrangements in the land is not fully protected.

The considerations militating for and against the introduction of of a registration system for interests in customary land, and the timing of the introduction of such a system, are well summarized by Professor H.W. West: 40

Timing the Introduction of Registration

Premature introduction before landowners appreciate the need for a system, or before there is any extensive market in property rights, or before land values have risen sufficiently to warrant the expenditure, all these will merely bring the system into disrepute. Premature introduction is unlikely to do any actual harm, but registration may degenerate into an expensive exercise in futility. Where social conditions and facilities are not yet ready for this service, the system is likely to operate only in a desultory manner, depending on heavy and continual government subsidy. Care must be taken to ensure that political considerations do not cause the ; establishment of registration of title before social and economic conditions can justify it.

On the other hand, delay in introducing registration may have more serious results. Delay may permit the proliferation of customary dealings, with or without evidence in writing, and so lead to clouded title and to litigation. In most circumstances the longer the introduction is postponed, the greater will be the problem of adjudication or conversion. The folly of delay may be illustrated from current experience in Ghana and Nigeria. 
In general it is preferable to establish registration too early rather than too late; and government may have to be prepared to subsidize heavily in the early stages.

Professor West in his paper goes on to address the central question of whether a registration system should be sporadic or systematic in nature:

In sporadic compilation the title of each parcel of land is determined separately, irrespective of where the land is situated and of when the application is presented.

In systematic compilation a particular area (which may be as large or as small as is expedient) is delimited and declared an adjudication area; all interests in land in that area are then determined and recorded.

When a register is being compiled, limited resources are bound to force a degree of selection into the procedure. Even in the systematic approach the actual areas to be systematically adjudicated must themselves be selected according to some rational order of priority.

Sporadic adjudication allows the greatest degree of selectivity in that title is adjudicated precisely when and where it is required; e.g. to select only those landholders capable of benefitting from institutional credit.

But sporadic adjudication suffers from a number of shortcomings:

(i) It involves a degree of repetition, can arouse unnecessary suspicion and requires adjudication staff to be permanently available.

(ii) Sporadic enquiry and individual registration lack the general publicity which is the greatest safeguard in systematic adjudication, and therefore presents a much greater opportunity for fraud and corruption, or merely 'oversight'. 
(iii) In the long term, piecemeal adjudication will be more expensive than systematic adjudication and the latter lends itself more satisfactorily to the planning of a work programme.

(iv) Sporadic adjudication entails the operation of two systems of law side by side for an indefinite period and delays in the establishment of a comprehensive investory of 1 and resources in respect of any given area, without which the abstraction of reliable statistical data is impossible.

The choice between a sporadic and a systematic system of registration is particularly important in a Papua New Guinean context. 41 Both previous efforts to register interests in customary land, i.e. the Native Land Registration Act of 1952 and the Land Titles Commission Act of 1962 adopted essentially a systematic approach to developing a registration system. Both attempts almost completely failed, with scarcely a single block of customary land being registered in either case. A major factor in the failure of these attempts appears to be that they were excessively ambitious in setting out to register all customary land in Papua New Guinea. The administrative resources devoted to this undertaking were not remotely adequate. The magnitude of the undertaking bears contemplation. In a country lacking a written history, comprising 700 separate tribes speaking 700 separate, non-mutually intelligible languages, espousing many different customary laws, recognising ownership as largely a function 
of the vicissitudes of tribal war, mostly defining ownership rights by reference to membership in often very large and ill-defined lineage and locational groups, and recognizing a multiplicity of different ownership and occupation interests in 1and, the problems and costs of developing, implementing and maintaining a documentary title system are nothing short of immense.

For these reasons, especially in the light of the limited availability of government resources, it is suggested that at least for the time being attempts should be directed at.developing a registration system that is sporadic in nature and is responsive to desires on the part of customary land-owners to engage in activities on their land or with their land which are facilitated by the existence of a registration system and the enhanced security of title that accompanies it. Thus, ambitions to register interests in customary land thoughout the country or even throughout major areas throughout the country, whether or not customary land-owners plan activities for their land that would be enhanced by a registry system, should be abandoned.

If this view should be accepted, the next major issue of what institutional or administrative apparatus is required to implement a registration system is partly answered. A sporadic registration system will have to be intimately linked to prevailing systems of 
land dispute resolution with respect to customary land. As was discovered in both the two previous attempts to establish a registration system in Papua New Guinea, the very act of embarking upon this exercise is likely to precipitate new land disputes given the "once and for all" character of the act of registration. Knetsch and Trebilcock in an earlier study on land policy in Papua New Guinea ${ }^{42}$ proposed that efforts be made to harness the resources of the existing land dispute resolution apparatus, i.e. local and provincial land courts, by extending their mandate to enable them to make binding declarations of rights in various contexts:

(1) Mediated agreements between previously disputing parties which, under the present provisions of the Land Disputes Resolution Act, become binding on the parties on registration of the agreement with the court.

(2) Decisions by local or provincial land courts on land disputes where mediation has previously failed.

(3) Declarations of rights sought on the application of a land-owning group contemplating development of its land but apprehensive about future adverse claims, especially if the development proves successful, or requiring to ensure security of tenure in order to induce third party involvement in the project. 
Consequential mechanics might operate approximately as follows. A local Land Court, on issuing an order declaring rights in land would forward it to the Provincial Land Court Magistrate's Office for filing, pending expiration of appeal periods or procedures. When these expire, the original Land Court order would be forwarded to the Registrar of Titles in Port Moresby for entry into the proposed register of customary land. A copy of the order would be retained by the Provincial Land Court Magistrate's Office. On receipt of the order, the Registrar of Titles would prepare a standardized abstract of the order, identifying the land-owning group, and describing the location, area, and demarcation of the land and the nature of the land-owning group's interest therein (typically base title only would be registered). A copy of this standardized abstract would be remitted to the Provincial Land Court Magistrate's office for filing in a regional duplicate register. Where leasing or security (mortgage) transactions are entered into by land-owners following a declaration of their rights by the Land Court, the N.P.M.A. (which must approve all leases but not mortgages under earlier proposals) in the first case and mortgagees in the second would bear responsibility for filing agreements with a Provincial Land Court Magistrate's office who would check, in the case of mortgages, that necessary consents had been obtained. The agreement would then be forwarded to the Registrar of Titles who would abstract it as above and forward a copy of the abstract to the relevant Provincial Land Court Magistrate's office for duplicate regional filing. The 
Registrar of Titles would, on entering an abstract in the central customary land register, in all cases also send a copy of the abstract to representative(s) of the land-owning groups named to act in that capacity in the Land Court order and to third parties involved in agreements. Under this set of propsals, a number of issues require further exploration:

(i) The Interests to be Registered

Experience to date in the Land Courts has apparently been that disputes almost invariably involve competing claims to base title to a piece of land rather than to the large number of possible subsidiary interest (e.g. the right to hunt, gather firewood, traverse, etc.) that may exist in customary land. In the case of undisputed applications for declarations of right, as a basis of agreements with third parties in furtherance of a scheme of development, base title will invariably be the central concern of the parties. It is proposed that only base title interests should initially be entered in the customary land registry and their registration should be without prejudice to subsidiary interests in the land unless the underlying Land Court order otherwise provides and this is so reflected in the register. 
Identification of the Land

At present, Land Courts in their orders apparently identify land by reference to:

(1) the land-owners by clan or village name;

(2) approximate area of the land;

(3) approximate location of the land;

(4) a simple map identifying key physical demarcation characteristics (surveys are not presently required).

A central question that must be resolved is whether in translating Land Court orders into customary land registry entries, surveys should 43

be required. Several options need further exploration:

(1) Simply to rely on physical demarcation characteristics and a simple map depicting these, as is present practice in the Land Courts, leaving it as an option open to the parties (e.g. where leasing or security agreements with third parties are contemplated) to conduct a survey and have this incorporated in the Land Court order.

(2) To require full-scale cadastral surveys in all cases; this would severely constrain and delay the whole process of registration and generate costs for customary land-owners that are likely to be a significant disincentive to development. This, therefore, seems an unattractive option. 
(3) To opt for a middle course and require low-quality surveys (e.g. compass and chain surveys by a class of certified technicians with fairly modest training and permitted to engage in private practice) as a component of registerable Land Court orders, leaving full-scale surveys as an option 44

for the parties. This may be the preferable option.

\section{(iii) Identification of the Parties}

Present Land Court practice is to identify land-owning groups, in Land Court orders, by reference to clan or village name without specifying the individual members. The C.I.L.M.'s recommendation on customary land registration would have required the latter. Several difficulties exist here. First, as the C.I.L.M. apparently discovered in its meetings across the country, the relevant conception of a group varies from region to region. In some regions, the Committee was asked to permit registration of nuclear families; in other areas sub-clans, in other areas clans, in other areas villages or wards embracing several clans. ${ }^{45}$ The C.I.L.M. proposed that the registration system should be flexible enough to accomodate these different conceptions of communal ownership. While this, on its face, seems sensible, a continuing conern remains to the extent that the recent anthropological analysis (noted above) of social groups in traditional cultures is well- 
founded - that most rights are not exercised by groups but by individuals or families with a certain set of rather fluid linking characteristics. In this case, to register a "group" without also registering its constituent members or the nature of their individual interests may be a somewhat arbitrary and limited exercise.

The question of whether all individual members of landowning groups should also be registered at the time of group registration is this a problematic one. Obviously, on the one hand, this would substantially complicate, in terms of delays and costs, the whole registration process. These complications will become more acute over time as intermarriage and concomitant problems of lineage definitions render issues of group membership increasingly confused and indeterminate. On the other hand, not to define group membership at the time of group registration may reduce the incidence of inter-group disputes, at the cost of increasing the incidence of intra-group disputes, particularly with respect to the distribution of financial or other. surpluses from agricultural development amongst group members. Traditional internal group rules developed in a subsistence setting, which define claims by families or subsets of a group on communal property, may not be adequate to the task of clearly and credibly determining the distribution of surpluses from communally-owned land. One might, in any event, predict that these rules will come under increasing stress with the generation of larger surpluses. This concern would 
be only partly met be registration of individual group members: this would do no more than identify who qualifies for participation in the returns from land. It would not determine the extent of that participation. On the other hand, to register not only individual members but the nature of their prior interests and what these translate into in terms of the sharings of returns from a group enterprise would seem an impossibly complex task.

On balance, there would seem to be a case in the early stages of operationalizing a rudimentary registration system for minimizing the administrative demands on the system by, in general, avoiding registration of individual group members. Fully individualized absolute property rights could continue to be enhanced by registration pursuant to the Land Tenure Conversion Act while communal property rights should perhaps only be registerable by groups following the incorporation of a land group where base-line constitutional requirements (noted above) may be able to ensure appropriate internal recognition and adjustment of individual claims against other group members.

\section{(iv) The Strength of State Support Required for: Customary Land} Title Registrations

Under the Torrens title system, where a party has been deprived of his land by fraud, forgery, etc., he has recourse against a Stateadministered insurance fund for compensation in the event that the land has since been transferred to an innocent third party, whose title is 
deemed indefeasible. The question arises whether the State should provide similar insurance to wrongfully deprived true owners under the system being proposed. It is submitted that there is not a strong case for such insurance. Under the system envisaged, the entire underpinnings of the customary land register will be Land Court orders issued after full notification to all potentially interestel parties of a pending proceeding and after due process has been accorded all affected parties in such proceedings. Moreover, registration of the Land Court order will not become determinative of rights to base title to the land until all avenues of appeal or time for appeals have expired. If these procedures are properly followed, adequate protection would seem to be provided to other parties with potentially adrerse claims to a piece of land to prosecute those claims. It is not obvious that there is a case for further protection in the form of subsequent compensation or insurance entitlements.

However, having argued that a rudimentary custoinary land register of the kind proposed need not involve major exposure by the State in terms of "true owner" insurance entitlements, it is important to stress, as earlier noted, that the State must be prepared to support the Land Court orders, once registered, either by enforcing them against parties who seek to defy them or by compensating parties who rely on such orders to their detriment (i.e. the registered land- 
owning group or third parties with which the group may subsequently have entered into leasing or security arrangements). This is absolutely integral to the effective functioning of a credible customary land register. In its absence, third parties simply will not be induced to enter into transactions with registered land-owning groups if a group's title is de facto defeasible by non-enforcement. The problem of nonenforcement of legal entitlements has been an acute problem in Papua New Guinea in the past. The difficulties cannot be gainsaid when large groups with intense passions are arrayed on each side of an issue. However, some apparatus must be set up to ensure that property rights, once determined, are reasonably inviolate and that in the event of the failure of the government effectively to enforce a Land Court order, an aggrieved group or party can apply for full compensation from the State. Perhaps a non-political agency such as the National Land Commission could, by extension of its present legislative mandate to review governmental compensation obligations in voluntary and compulsory acquisitions, be given this function. Contingent liabilities under this proposal could be partly financed out of small filing levies on registrants of orders or agreements in the customary land register. 
Perhaps a more attractive general source of financing for all aspects of the proposed registration system is Iand taxes (the constitutional preserve of provincial governments). At present, these are levied only on alienated land, where the registration system enables ready identification of land-owners or lessees. Becaus z no customary land is registered, it has been impracticable to impose land taxes on this land, despite extensive economic activities being undertaken on much of it. Under a system of sporadic registration, a land tax could be imposed on registered land-owners, part of the proceeds of which could be employed to underwrite the costs of the registration system. Such a possibility has several attractions. First, it offers a strong incentive to financially straightened provincial governments to garner the political will to support customary land law reform, although because registration will be elective, a measure of discipline will exist as to the level of tax imposed. Second, it will discourage land-owners with no development plans in mind from availing themselves of, and perhaps overloading, the system, when there are no significant economic returns from registration (Whatever the strategic advantages for the registrants in incipient disputes with neighbours). Third, it minimizes the budgetary implications for the central government of embarking upon such reforms. 


\section{(c) Conclusions}

I have tried to sketch the outlines of a rudimentary system (1) for permitting limited direct dealing (mortgages and leases) in customary land, (2) for reducing the transaction costs associated with present group decision-rules by facilitating the incorporation of land groups, and (3) for enabling sporadic registration of reasonably secure base title to customary land in cases where this is necessary for the development of land. In developing these proposals, I have sought to avoid that the two polar policy paradigms that have dominated debates on 1 and reform in Papua New Guinea to date - the preservation of the traditional status quo in which all changes are viewed as subversions of a pure or pristine original culture ( a kind of "noble savage" paradigm) or complete individualization of all property rights in land with total freedom of alienability (a capitalist-driven concept of economic development as an over-riding policy objective). The menu of available policy options and concomitant institutional arrangements seems much richer than this and the possibie sets of trade-offs much more subtle. It is not obvious why measured and cautious changes need produce Mead's degenerate twilight world. While some change is inevitable and some economic development widely considered desirable, it is not necessary to conclude from this that unrestrained propulsion through the development threshhold is now the only option. The strong survival characteristics of 
many traditional institutions suggest valued social qualities that should not be too readily discounted or abandoned.

The proposals outlined in this essay also attempt to minimize both the amount and the sophistication of bureaucratic resources required to make a rudimentary system function effectively. The resources sought to be deployed are already essentially in place and performing related functions to those envisaged under the proposals, i.e. the N.P.M.A., the Land Courts, the National Land Commission, and the Registrar of Titles. Those bureaucratic resources that are the indispensable minimum to make the system function are, in the case of the N.P.M.A. and the Land Courts, widely decentralized and readily accessible to land-owning groups with an interest in developing their land. Moreover, in the case of the N.P.M.A. (as reconstituted), the proposals assign it a lynch-pin role in shifting the whole bureaucratic posture towards land administration from an inhibitory one (as represented by the present procedures of the Department of Lands) to a facilitative one. Thus, the proposals seek not only to minimize bureaucratic resources but also to change the whole nature of their orientation. Finally, the proposals attempt to focus resources on areas of iand administration from which the economic pay-offs and second-order demonstration effects will be greatest: customary land-owning groups who have developable land and a desire to develop it and where land disputes 
do not inhibit its development or make special demands on the capacity and credibility of the legal system. By avoiding cataclysmic (and unattainable) agendas of reform and by focussing on a few "soft" but crucial margins, it may be possible to unlock the policy paralysis that has been generated by the ofren anguished debates on land reform in Papua New Guinea over many decades.

In a wider context, the Papua New Guinean experience instructively highlights the critical relationship in every society between the legal system which defines, enforces, and governs the transferability of property rights, and the rate and patterns of economic development that will be induced by the choice of property rights regime. Property rights - and social choices about their configuration - are at the heart of the functioning of every economic system. Understanding the interaction between legal rules and economic incentives is a necessary aid to the making of these social choices. For Papua New Guineans, these choices about property rights - in fundamental respects still to be confronted - will largely determine the future shape and structure of their society. 
FOOTNOTES

1. James Griffin, Hank Nelson and Stewart Firth, Papua New Guinea, A Political History, (Heinemann Education, Australia, 1979), chap. 1.

2. See Michael J. Trebilcock, The Role of the Private Sector in the Economic Development of Papua New Guinea, Institute of National Affairs, Port Moresby, Papua New Guinea (forthcoming).

3. World Bank Report on Papua New Guinea, December, 1981.

4. Ibid., pp. $25,34,61$.

5. R. Crocombe and R. Hide, "New Guinea: Unity in Diversity" in R. Crocombe (ed.) Land Tenure in the Pacific (Oxford University Press, Melbourne, 1971) at p. 298 et seq.

6. H.C. Brookfield and P. Brown, Struggle for Land (Oxford University Press, Melbourne, 1963), chaps. V, VII, XIII.

7. B. Malinowski, Coral Gardens and Their Magic (American Book Co., N.Y., 1935), chaps. XI and XII, esp. Pp. 379, 380 .

8. Crocombe and Hide, op. cit., p. 301

9. Brookfield and Brown, op. cit., chap. XI.

10. Roy Wagner, "Are There Social Groups in the New Guinea Highlands?", in Murray Lea (ed.) Frontiers in Anthropology (N.Y. Van Nostrand, 1974); Andrew Strathern, "Kinship, Descent and Locality: Some New Guinea Examples" in J. Goody, The Character of Kinship (Cambridge University Press).

11. Wagner, ibid., p. 99.

12. Theo Bredmeyer, "The Registration of Customary Land in Papua New Guinea", (1975) 3 Melanesian Law Journal 267.

13. Owen Jessep, Land Demarcation in New Ireland, History of Agriculture, Working Paper No. 41, mimeo, n.d.

14. Bredmeyer, op. cit.

15. S. Rowt on Simpson, "Land Problems in Papua New Guinea", in Land Tenure and Economic Development, (New Guinea Research Bulletin No. 40, ANU, 1971). 
16. Alan Ward, "Customary Land, Land Registration and Social Equality in Papua New Guinea", History of Agriculture Discussion Paper No: 20, Uni. P.N.G., 1978.

17. Report of the Commission of Inquiry into Land Matters (C.I.L.M.), Port Noresby, October, 1973.

18. B.G. Burton-Bradley, "The Psychological Dimension", in Peter G. Sack (ed.) Problem of Choice, Land in Papua New Guinea's Future, (ANU Press, 1974), p. 32 .

19. Richard A. Posner, "A Theory of Primitive Society, with Special Reference to Law", (1980) $23 \mathrm{~J}$. Law and Economics 1.

20. Posner, "Utilitarianism, Economics, and Social Theory", (1979) $8 \mathrm{~J}$. Legal Studies 103.

21. cf. Karl Polanyi, The Great Transformation, (Beacon Press, Boston, 1947.)

22. Polanyi, op. cit.

23. Margaret Mead, Growing Up in New Guinea (William Morrow and Co., N.Y., 1930), p. 3 .

24. Margaret Mead, New Lives For 01d (William Morrow and Co., N.Y., 1956), p. 440 et seq.

25. Polanyi, op. cit., chap. 15.

26. A.M. Healy, "Land Problems and Land Policies in Kenya and Papua New Guinea", in Land Tenure and Economic Development (New Guinea Research Bulletin No. 40, Australian Natural University, 1971), p. 106. For further descriptions of land reform in Kenya, see $J$. Kinyanjui, "Land Reform in Kenya", in Land Tenure and Economic Development id., and Bredmeyer, "The Kenyan Model", in Sack op. cit., chap. 7 .

27. Ibid at p. 105 .

28. See Maine, Ancient Law, (London, John Murray, 1916) pp. 134, 135, 172-174; Village Communities (2nd ed, London, John Murray,) pp. $194-197$.

29. See S. Rowton Simpson, Land Law and Registration (Cambridge University Press, 1976), pp. 225, 226. 
30. Olewale, "The Price of Progress", in Sack op. cit., at pp. 43, 44.

31. See generally on problems of rural-urban migration in developing countries, Michael P. Todaro, Economic Development in the Third World. (2nd ed., N.Y., Longman, (1981)), chaps. 9 and 10.

32. Healy, op. cit., pp. 86, 87; Orken, "They Fight For Fun", in Sack op. cit., p. 150.

33. Harold Demsetz, "Toward a Theory of Property Rights", (1967) 57 American Economic Review 347.

34. Op. cit.

35. See generally Todaro, op. cit.

36. Ward, op. cit.

37. Op. cit.

38. Albert 0. Hirshman, A Bias For Hope (Yale University Press, 1971), p. 6 .

39. Op. cit., pp. 30-33.

40. "Registration of Title: Some Practical Issues in Policy Making (with Particular Reference to African Experience)", Cambridge, U.K., 1975, mimeo.

41. Extensive discussions of the characteristics of land registration systems in countries with customary forms of land tenure are to be found in S. Rowton Simpson, Land Law and Registration, op. cit., and R.G. Crocombe, Improving Land Tenure (South Pacific Commission, Noumea, New Caledonia, 1975).

42. Jack L. Knetsch and Michael J. Trebilcock, Land Policy and Economic Development in Papua New Guinea, Institute of National Affairs, Port Moresby, Papua New Guinea, 1981.

43. For an extensive dicussion of issues of parcel definition and boundary demarcation, see Rowt on Simpson, Land Law and Registration op. cit., chap. 8.

44. See B.J. Mennis, Assistant Surveyor General, "Low Accuracy Surveys", 17 th Survey Congress, Association of Surveyors of Papua New Guinea, Port Moresby, Papua New Guinea, 16th-20th August, 1982.

45. Op. cit., p. 28. 